\title{
Pewarisan Karakter Kualitatif dan Kuantitatif pada Hipokotil dan Kotiledon Tomat (Solanum lycopersicum L.) Silangan IPB T64 x IPB T3
}

\author{
Inheritance of Qualitative and Quantitative Characters on Tomato \\ (Solanum lycopersicum L.) Hypocotyl and Cotyledon
}

\author{
Marlina Mustafa $^{1,2}$, Muhamad Syukur ${ }^{3}$, Surjono Hadi Sutjahjo ${ }^{3}{\text { dan } \text { Sobir }^{3}}^{3}$
}

Diterima 21 Maret 2016/Disetujui 26 Oktober 2016

\begin{abstract}
Hypocotyl and cotyledon are potentially used as effective morphological markers since they can be detected earlier. Information on inheritance of tomato hypocotyl and cotyledon was not available. The aims of this research was to study the inheritance of qualitative and quantitative characters of tomato hypocotyl and cotyledon. This research used six population, P1 green hypocotyl (IPB T64), P2 purple hypocotyl (IPB T3), F1, F1R, BCP1, BCP2, and F2. Analysis of qualitative characters used Mendelian and gene action of quantitative characters used joint scaling test. The results of Mendelian indicated that the character of hypocotyl color was controlled by two genes of dominant-recessive epistasis. The gene controlling purple color was dominant to the green color gene. Based on the F2 distribution test, hypocotyl length, cotyledon length and width were controlled by polygenes. There was no influence of maternal effect. The results of the joint scaling test showed gene action of hypocotyl length was controlled by additive gene with influence of additive-dominant epistasis. Length and width of the cotyledon were controlled by additive gene and influence of duplicate epistasis effect. All characters had high level of broad sense heritability and medium level of narrow sense heritability.
\end{abstract}

Keywords: cotyledone, gene action, heritability, hypocotyle, morphology marker.

\begin{abstract}
ABSTRAK
Hipokotil dan kotiledon berpotensi untuk dijadikan sebagai marka morfologi yang efektif karena dapat dideteksi lebih dini. Informasi pola pewarisan karakter hipokotil dan kotiledon tomat belum banyak tersedia. Penelitian ini bertujuan untuk mempelajari pola pewarisan karakter kualitatif dan kuantitatif dari hipokotil dan kotiledon tomat sebagai marka morfologi pada tahap awal pertumbuhan tanaman. Penelitian ini menggunakan enam set populasi yaitu P1 hipokotil hijau (IPB T64), P2 hipokoti ungu (IPB T3), F1, F1R, BCP1, BCP2, dan F2. Karakter kualitatif menggunakan analisis Mendel dan pendugaan aksi gen karakter kuantitatif menggunakan analisis skala gabungan. Hasil analisis Mendel menunjukkan bahwa karakter warna hipokotil dikendalikan oleh dua pasang gen epistasis dominan-resesif. Gen pengendali warna ungu bersifat dominan terhadap warna hijau pada hipokotil tomat. Panjang hipokotil, panjang dan lebar kotiledon dikendalikan oleh banyak gen dan tidak ada pengaruh tetua betina berdasarkan uji sebaran populai F2. Hasil analisis skala gabungan menunjukkan bahwa aksi gen karakter panjang hipokotil dikendalikan oleh gen aditif dengan pengaruh epistasis aditif dominan, panjang dan lebar kotiledon dikendalikan oleh gen dominan dengan pengaruh epistasis duplikat. Semua karakter yang diamati memiliki nilai heritabilitas arti luas dalam tingkatan yang tinggi, sedangkan heritabilitas arti sempit dalam tingkatan yang sedang.
\end{abstract}

Kata kunci: aksi gen, heritabilitas, hipikotil, kotiledon, marka morfologi.

\footnotetext{
${ }^{1}$ Program Studi Pemuliaan dan Bioteknologi Tanaman, Sekolah Pascasarjana, Institut Pertanian Bogor.

${ }^{2}$ Jurusan Agroteknologi, Fakultas Pertanian Perikanan dan Peternakan, Universitas Sembilanbelas November Kolaka

J1. Pemuda No. 399 Kolaka, Sulawesi Tenggara, Indonesia.

${ }^{3}$ Departemen Agronomi dan Hortikultura, Fakultas Pertanian, Institut Pertanian Bogor (Bogor Agricultural University)

Jl. Meranti, Kampus IPB Darmaga, Bogor 16680, Indonesia

Email: muhsyukur@yahoo.com (*penulis korespondensi)
} 


\section{PENDAHULUAN}

Tomat (Solanum lycopersicum L.) adalah salah satu tanaman hortikultura yang penting bagi pemulia karena dapat digunakan sebagai tanaman model untuk mengetahui gen penting yang berpengaruh pada pertumbuhan tanaman dikotil (Wing et al., 1994). Karakterisasi tomat yang telah ditetapkan oleh UPOV (2011) menunjukkan bahwa terdapat keanekaragaman genetik pada beberapa karakter tomat, sehingga untuk mendapatkan karakter yang diinginkan perlu dilakukan seleksi.

Seleksi untuk perbaikan suatu karakter dapat dilakukan secara langsung pada karakter yang dituju atau secara tidak langsung melalui karakter yang lain (Villanueva dan Kennedy, 1990; Syukur et al., 2015). Seleksi tidak langsung dapat dilakukan pada tahap awal (Villanueva dan Kennedy, 1991). Kim et al. (2011) menggunakan fase bibit untuk mengevaluasi varietas yang resisten terhadap beberapa penyakit pada tomat, seleksi lebih efisien daei segi waktu dan biaya.

Warna hipokotil pada tomat dapat digunakan sebagai marka pada uji hibriditas untuk mengetahui kebenaran varietas hibrida secara genetik (Syukur et al., 2015). Selain itu, Ibarra-Perez et al. (1996) juga menggunakan warna hipokotil untuk mengevaluasi produksi benih hibrida pada kacang buncis (Phaseolus vulgaris L. Fabaceae). Penelitian Gumelar et al. (2014) menunjukkan bahwa terdapat genotipe lokal tomat yang tahan dan rentan terhadap serangan layu bakteri. Adapun Groenewegen et al. (1994) dan Reevesii (1973) menggunakan warna hipokotil untuk menentukan tingkat penyerbukan silang alami pada tomat. Kim et al. (2012) melaporkan bahwa warna hipokotil hijau berhubungan dengan karakter penting seperti GMS (Genetic Male Sterility) dan resistensi terhadap bacterial wilt, ToMV (Tobacco Mosaic Virus) dan FCRR (Fusarium Crown and Root Rot), sehingga warna hipokotil digunakan sebagai marka morfologi pada galur elit.

Pemilihan suatu karakter untuk dijadikan sebagai marka morfologi memerlukan informasi tentang pola pewarisan sifat dari karakter tersebut, sehingga seleksi yang dilakukan lebih efektif dan efisien. Jones et al. (2003) dan Kim et al. (2012) menggunakan marka molekuler untuk mengidentifikasi pewarisan warna hipokotil pada tomat. Namun, penggunaan marka molekuler membutuhkan biaya yang cukup mahal, sehingga marka lain yang lebih efisien dari segi biaya. Penggunaan karakter hipokotil dan kotiledon tomat berpotensi untuk dijadikan sebagai marka seleksi karena dapat dideteksi secara dini sebagai karakter awal pertumbuhan tanaman yang dapat berpengaruh terhadap fase pertumbuhan selanjutnya. Akan tetapi, pemilihan suatu karakter untuk dijadikan sebagai marka morfologi memerlukan informasi tentang pola pewarisan sifat dari karakter tersebut, sehingga seleksi yang dilakukan lebih efektif dan efisien. Oleh karena itu, penelitian pola pewarisan sifat karakter kualitatif dan kuantitatif pada hipokotil dan kotiledon tomat menjadi penting untuk dilakukan. Penelitian ini bertujuan untuk mempelajari pola pewarisan sifat beberapa karakter kualitatif dan kuantitatif pada hipokotil dan kotiledon tomat sebagai marka morfologi pada tahap awal pertumbuhan tanaman.

\section{BAHAN DAN METODE}

Percobaan dilakukan di Kebun Percobaan Leuwikopo dan Laboratorium Pemuliaan Tanaman, Departemen Agronomi dan Hortikultura, Fakultas Pertanian, Institut Pertanian Bogor pada Bulan Januari 2013 sampai dengan Januari 2015. Materi genetik yang digunakan terdiri atas tetua $(\mathrm{P} 1)$ tomat dengan hipokotil berwarna hijau (IPB T64) sebanyak 65 bibit, tetua (P2) tomat dengan hipokotil berwarna ungu (IPB T3) sebanyak 60 bibit; turunan pertama (F1) sebanyak 60 bibit; turunan pertama resiprokal (F1R) sebanyak 65 bibit; silang balik pada tetua betina (BCP1) sebanyak 178 bibit dan silang balik pada tetua jantan sebanyak 84 bibit, dan populasi turunan kedua (F2) sebanyak 1004 bibit untuk karakter kualitatif dan 402 bibit untuk karakter kuantitatif.

Penyemaian benih dilakukan pada tray menggunakan media steril untuk pengujian karakter kualitatif dan kuantitatif dengan dua benih per lubang tray. Penyemaian benih juga dilakukan dengan menggunakan media kertas tissue yang diletakkan dalam kotak plastik mika transparan berukuran $20 \mathrm{~cm} \times 20 \mathrm{~cm}$ untuk pengujian karakter kualitatif. Kertas 
tissu dibasahi air sampai jenuh kemudian dimasukkan ke dalam kotak plastik. Penyiraman bibit tanaman pada tray dilakukan setiap hari dengan cara dikocor, sedangkan bibit tanaman pada kotak plastik disemprot air menggunakan handsprayer. Pengamatan peubah dilakukan setelah kotiledon terbuka sempurna yaitu pada saat berumur 7-10 hari setelah semai.

Peubah pengamatan terdiri atas warna hipokotil, panjang hipokotil $(\mathrm{cm})$, panjang kotiledon $(\mathrm{cm})$, dan lebar kotiledon $(\mathrm{mm})$. Karakter kualitatif dianalisis menggunakan analisis genetik mendel, sedangkan analisi karakter kuantitatif mengikuti metode yang digunakan Arif et al. (2012), Ritonga (2013), dan Shalaby (2013). Analisis data karakter kuantitatif tersebut terdiri atas pendugaan pengaruh tetua betina, uji kenormalan data, derajat dominansi, kelayakan model genetik, komponen ragam, dan heritabilitas.

\section{HASIL DAN PEMBAHASAN}

\section{Pewarisan Karakter Tomat Persilangan Genotipe IPB T64 x IPB T3}

Karakteristik tomat pada fase bibit dideskripsikan berdasarkan keberadaan pewarnaan antosianin pada hipokotil (UPOV, 2011). Terdapat dua macam warna hipokotil yang diamati pada penelitian ini, yaitu ungu dan hijau. Genotipe tomat IPB T64 (P1) memiliki hipokotil berwarna hijau, sedangkan genotipe tomat IPB T3 (P2) memiliki hipokotil berwarna ungu. Tanaman F1 dan F1R menghasilkan hipokotil yang semuanya berwarna ungu. Hasil analisis genetik Mendel untuk karakter warna hipokotil pada generasi F2 menghasilkan nisbah fenotipe 13 ungu: 3 hijau, sedangkan pada populasi BCP1 menghasilkan nisbah fenotipe 2 ungu: 1 (Tabel 1). Hal ini menunjukkan bahwa karakter warna hipokotil dikendalikan oleh dua pasang gen epistasis dominan-resesif (Sobir dan Syukur, 2015). Menurut Kim et al. (2012) dan Rotonga (2013) warna hipokotil dikendalikan oleh gen dominan tunggal. Gen pengendali warna hipokotil ungu dominan terhadap warna hijau.

Penelitian Jones et al. (2003) pada pewarisan antosianin buah tomat diperoleh rasio BCP1 2 ungu: hijau 1, akan tetapi rasio pada generasi F2 adalah 3 ungu: 1 hijau. Antosianin pada jaringan vegetatif pada kemangi (Ocimum basilicum L.) dikendalikan oleh dua gen dominan sedangkan pada daun dikendalikan oleh gen resesif tunggal (Phippen dan Simon, 2000). Pewarisan karakter antosianin sangat kompleks (Knievel et al., 2009) dan belum stabil pada beberapa tanaman menyerbuk sendiri (Phippen dan Simon, 2000).

\section{Pengaruh Tetua Betina terhadap Pewarisan Karakter Hipokotil dan Kotiledon Tomat Silangan Genotipe IPB T64 x IPB T3}

Hasil uji kehomogenan ragam dan pengaruh tetua betina mengunakan uji $\mathrm{F}$ dan uji beda nilai tengah (uji t) menunjukkan bahwa tidak terjadi perbedaan nyata antara F1 dan F1R untuk semua karakter yang diamati (Tabel 2). Hasil uji t menunjukkan bahwa tidak terdapat pengaruh tetua betina, sehingga mengindikasikan hanya gen-gen dalam inti yang mengendalikan pewarisan karakterkarakter tersebut.

Tabel 1. Nilai $x^{2}$ hitung warna hipokotil pada populasi P1 (IPB T64), P2 (IPB T3), BCP1 (F1 x IPB T64), BCP2 (F1 x IPB T3) dan F2 (IPB IPN T64 x IPB T3)

\begin{tabular}{llrrrrr}
\hline Populasi & \multicolumn{1}{c}{ Fenotipe } & Nisbah & Harapan & Pengamatan & $\mathrm{X}^{2}$ hitung & $\mathrm{X}^{2}$ tabel \\
\hline P1 & $100 \%$ berwarna hijau & & & & & \\
P2 & $100 \%$ berwarna ungu & & & & & \\
F1 & $100 \%$ berwana ungu & & & & & \\
F1R & $100 \%$ berwana ungu & & & & & \\
F2 & Ungu $:$ Hijau & $13: 3$ & $815.75: 188.25$ & $839: 165$ & $3.46^{\text {tn }}$ & 3.84 \\
BCP1 & Ungu $:$ Hijau & $2: 1$ & $118.67: 59.33$ & $126: 52$ & $1.24^{\text {tn }}$ & 3.84 \\
BCP2 & $100 \%$ berwana ungu & & & & & \\
\hline
\end{tabular}

Keterangan: $\mathrm{tn}=$ tidak nyata pada taraf $\alpha=5 \%$ 
Tabel 2. Uji pengaruh tetua betina pada karakter hipokotil dan kotiledon tomat hasil persilangan Genotipe IPB T64 x IPB T3

\begin{tabular}{lccc}
\hline Populasi & Panjang Hipokotil & Panjang Kotiledon & Lebar Kotiledon \\
\hline F1 & $3.83 \pm 0.07$ & $2.21 \pm 0.04$ & $7.56 \pm 0.12$ \\
F1R & $3.71 \pm 0.07$ & $2.14 \pm 0.03$ & $7.42 \pm 0.12$ \\
Prob >f hit & $1.07^{\text {tn }}$ & $1.22^{\text {tn }}$ & $1.22^{\text {th }}$ \\
Prob > t hit & $1.33^{\text {tn }}$ & $0.97^{\text {tn }}$ & $0.78^{\text {th }}$ \\
\hline
\end{tabular}

Keterangan: $\operatorname{tn}=$ tidak nyata pada taraf $\alpha=5 \%$

Uji kehomogenan menunjukkan bahwa ragam F1 dan F1R homogen sehingga pada analisis selanjutnya materi genetik dari F1 dan F1R dapat digabungkan. Hasil ini sesuai dengan yang dilakukan Weber (1959) dan Ritonga (2013) pada tomat dan cabai bahwa tidak terdapat pengaruh tetua betina dalam pewarisan panjang hipokotil, serta panjang dan lebar kotiledon.

\section{Uji Sebaran Populasi F2 Tomat Hasil Persilangan Genotipe IPB T64 x IPB T3}

Pendekatan untuk menduga kendali genetik dapat berupa pendugaan deskriptif menggunakan skewness dan kurtosis (Roy, 2000). Hasil sebaran data penelitian berdasarkan kurva sebaran populasi F2 pada karakter panjang hipokotil, panjang dan lebar kotiledon bersifat kontinyu dan berbentuk platykurtic (Gambar 1). Panjang hipokotil memiliki skewness -0.05 dan kurtosis -0.38 , panjang kotiledon memiliki skewness 0.11 dan kurtosis - 0.47 , sedangkan lebar kotiledon memiliki skewness -0.27 dan kurtosis 0.18 (Tabel 3). Menurut Sihaloho et al. (2015) sebaran data yang bersifat kontinyu dikendalikan oleh banyak gen, yang ditunjukkan oleh nilai kurtosis -3 < kurtosis < 3 (berbentuk mesokurtic), sedangkan karakter yang dikendalikan oleh sedikit gen ditunjukkan oleh nilai kurtosis $>3$ (berbentuk leptokurtic) atau < -3 (berbentuk platikurtic) (Roy, 2000).

Sebaran data dengan nilai skewness nol mencerminkan bahwa karakter tersebut dikendalikan oleh aksi gen aditif, skewness positif adalah aksi gen aditif pengaruh epistasis komplementer, sedangkan untuk skewness negatif mencerminkan kendali gen aditif dengan pengaruh epistasis duplikat (Roy, 2000). Berdasarkan informasi tersebut maka dapat dikatakan bahwa karakter panjang hipokotil dan lebar kotiledon dikendalikan oleh banyak gen dengan aksi gen aditif dengan pengaruh epistasis duplikat, sedangkan panjang kotiledon dikendalikan oleh banyak gen dengan pengaruh epistasis komplementer. Ritonga (2013) serta Daya dan Prasad (1983) bahwa panjang hipokotil, serta panjang dan lebar kotiledon pada cabai dan lobak dikendalikan oleh banyak gen, sedangkan menurut Liang et al. (2014) panjang hipokotil pada kedelai dikendalikan oleh empat gen secara aditif dan menurut Weber (1959) pewarisan hipokotil dan kotiledon pada tomat dikendalikan oleh sedikit gen dengan aksi gen aditif.

Tabel 3. Potensi rasio, nilai skewness dan kurtosis pada populasi F2 karakter panjang dan lebar kotiledon

\begin{tabular}{ccccc}
\hline Karakter & Potensi Rasio & Aksi Gen & Skewness & Kurtosis \\
\hline Panjang Hipokotil & 0.96 & Dominan parsial & -0.05 & -0.38 \\
Panjang Kotiledon & 0.16 & Dominan parsial & 0.11 & -0.47 \\
Lebar Kotiledon & 1.99 & Overdominan & -0.27 & 0.18 \\
\hline
\end{tabular}



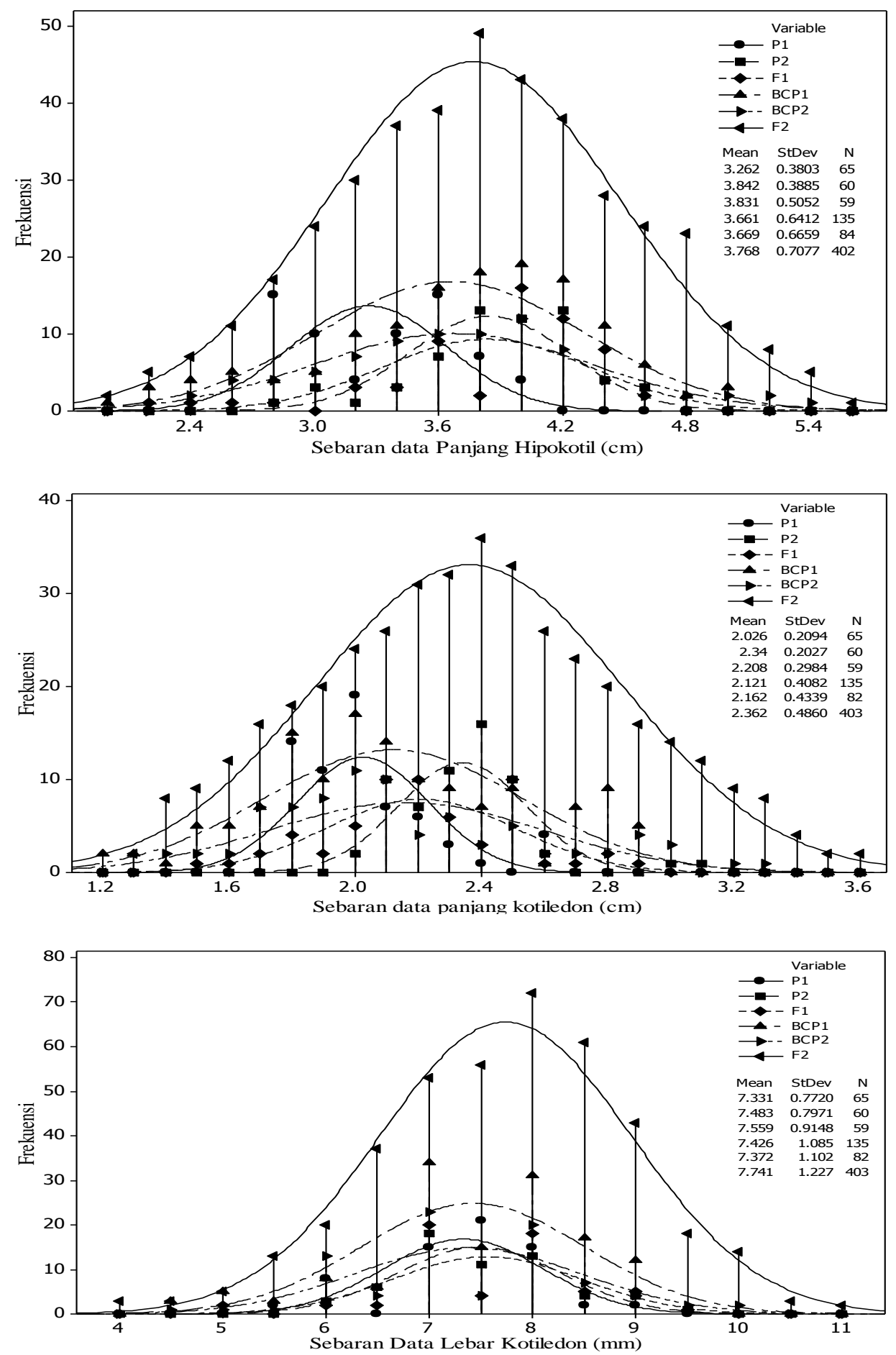

Gambar 1. Sebaran populasi P1, P2, BCP1, BCP2, dan F2 panjang hipokotil, panjang kotiledon dan lebar kotiledon tomat.

\section{Aksi Gen pada Karakter Hipokotil dan Kotiledon Tomat Hasil Persilangan Genotipe IPB T64 x IPB T3}

Karakter panjang hipokotil dan panjang kotiledon memiliki nilai potensi rasio yang berada pada kisaran 0 sampai 1 , sedangkan lebar kotiledon lebih dari 1 (Tabel 3). Hal ini mengindikasikan bahwa karakter panjang hipokotil dan kotiledon dikendalikan oleh aksi gen dominan parsial, sedangkan karakter lebar 
kotiledon dikendalikan oleh aksi gen overdominan. Weber (1959) melaporkan bahwa karakter panjang hipokotil dan kotiledon bersifat dominan pada tanaman tomat. Karakter lain pada tomat yang dikendalikan oleh aksi gen dominan parsial hingga overdominan adalah jumlah cabang primer per tanaman (Solieman et al., 2013) dan jumlah buah per tanaman (Dordevic et al., 2010; Farzane et al., 2012). Akan tetapi aksi gen berdasarkan nilai potensi ratio diestimasi pada generasi awal (F1) sehingga terbatas pada pengaruh aksi gen dominan atau resesif, sedangkan pengaruh aditif dan epistasis belum dapat diduga, sehingga perlu pendugaan aksi gen pada generasi F2. Analisis generasi F2 lebih kompleks karena dapat mendeteksi interaksi antar alel (Rodriquez et al., 2010).

Uji skala individu pada karakter panjang hipokotil serta panjang kotiledon dan lebar kotiledon menunjukkan hasil nyata pada salah satu skala A, B atau C (Tabel 4). Menurut Mather dan Jinks (1982) hasil uji skala individu yang tidak berbeda nyata menandakan aksi gen berupa aditif dominan, tetapi jika terdapat hasil nyata pada salah satu skala maka terdapat interaksi interalelik atau epistasis, sehingga untuk menentukan model yang paling sesuai harus dilakukan uji skala gabungan.

Model yang paling sesuai berdasarkan uji skala gabungan adalah model yang menunjukkan nilai $\mathrm{X}^{2}$ hitung terkecil dan lebih kecil dari $X^{2}$ tabel (Mather dan Jinks, 1982). Model genetik yang sesuai untuk karakter panjang hipokotil adalah aditif-dominan dengan pengaruh interaksi aditif $\mathrm{x}$ aditif dan aditif $x$ dominan dengan lima komponen $\mathrm{m}[\mathrm{d}][\mathrm{h}][\mathrm{i}][\mathrm{j}]$, sedangkan untuk karakter panjang dan lebar kotiledon adalah aditif $\mathrm{x}$ dominan dengan pengaruh interaksi aditif $\mathrm{x}$ aditif dan dominan $\mathrm{x}$ dominan dengan lima komponen $\mathrm{m}[\mathrm{d}][\mathrm{h}][\mathrm{i}][\mathrm{l}]$ (Tabel 5). Hasil ini sesuai dengan yang didapatkan oleh Rotonga (2013) pada karakter panjang hipokotil, panjang dan lebar kotiledon cabai.

Tabel 4. Hasil uji skala persilangan IPB T64 x IPB T3

\begin{tabular}{lccc}
\hline \multirow{2}{*}{ Karakter } & \multicolumn{3}{c}{ Uji Skala } \\
\cline { 2 - 4 } & \multicolumn{1}{c}{$\mathrm{A}$} & $\mathrm{B}$ & $\mathrm{C}$ \\
\hline Panjang Hipokotil & $0.231^{\mathrm{tn}} \pm 0.137$ & $-0.334^{*} \pm 0.167$ & $0.309^{\mathrm{tn}} \pm 0.205$ \\
Panjang Kotiledon & $0.008^{\text {tn }} \pm 0.084$ & $-0.224^{*} \pm 0.107$ & $0.663^{*} \pm 0.130$ \\
Lebar Kotiledon & $-0.038^{\text {tn }} \pm 0.241$ & $-0.299^{\text {tn }} \pm 0.290$ & $1.030^{*} \pm 0.369$ \\
\hline
\end{tabular}

Keterangan: * model tidak sesuai pada taraf $\alpha=5 \%$, tn model sesuai pada taraf $\alpha=5 \%$.

Tabel 5. Uji kecocokan model genetik untuk karakter hipokotil dan kotiledon tomat hasil persilangan genotipe IPB T64 x IPB T3

\begin{tabular}{lrlrlrl}
\hline Model Genetik & Panjang Hipokotil & Panjang Kotiledon & Lebar Kotiledon \\
\hline $\mathrm{m}[\mathrm{d}]$ & 34.47 & $* *$ & 46.20 & $* *$ & 17.88 & $* *$ \\
$\mathrm{~m}[\mathrm{~d}][\mathrm{h}]$ & 11.15 & $* *$ & 41.25 & $* *$ & 14.42 & $* *$ \\
$\mathrm{~m}[\mathrm{~d}][\mathrm{h}][\mathrm{i}]$ & 8.76 & $* *$ & 17.12 & $* *$ & 5.74 & tn \\
$\mathrm{m}[\mathrm{d}][\mathrm{h}][\mathrm{j}]$ & 3.89 & tn & 40.35 & $* *$ & 14.34 & $* *$ \\
$\mathrm{~m}[\mathrm{~d}][\mathrm{h}][\mathrm{l}]$ & 9.93 & $* *$ & 33.23 & $* *$ & 12.16 & $* *$ \\
$\mathrm{~m}[\mathrm{~d}][\mathrm{h}][\mathrm{i}][\mathrm{j}]$ & 1.52 & tn & 16.35 & $* *$ & 5.66 & $* *$ \\
$\mathrm{~m}[\mathrm{~d}][\mathrm{h}][\mathrm{i}][\mathrm{l}]$ & 8.39 & $* *$ & 3.49 & th & 0.59 & th \\
$\mathrm{m}[\mathrm{d}][\mathrm{h}][\mathrm{j}][\mathrm{l}]$ & 3.20 & tn & 32.86 & $* *$ & 12.14 & $* *$ \\
\hline
\end{tabular}

Keterangan: ** model tidak sesuai pada taraf $\alpha=5 \%$, tn model sesuai pada taraf $\alpha=5 \%$ 
Tabel 6. Pendugaan komponen genetik untuk karakter hipokotil dan kotiledon tomat hasil persilangan IPB T64 x IPB T3

\begin{tabular}{ccccccc}
\hline \multirow{2}{*}{ Karakter } & \multicolumn{7}{c}{ Komponen Genetik } \\
\cline { 2 - 7 } & $\mathrm{m}$ & $\mathrm{d}$ & $\mathrm{h}$ & $\mathrm{i}$ & $\mathrm{j}$ & $\mathrm{1}$ \\
\hline Panjang Hipokotil & $3.70^{*}$ & $-0.29^{*}$ & $0.10^{\mathrm{tn}}$ & $-0.16^{\text {tn }}$ & $0.51^{*}$ & - \\
Panjang Kotiledon & $2.99^{*}$ & $-0.15^{*}$ & $-1.76^{*}$ & $-0.82^{*}$ & - & $0.97^{*}$ \\
Lebar Kotiledon & $8.71^{*}$ & $-0.05^{\text {tn }}$ & $-2.75^{*}$ & $-1.31 *$ & - & $1.59^{*}$ \\
\hline
\end{tabular}

Keterangan: $\mathrm{m}=$ nilai tengah; $\mathrm{d}=$ pengaruh aditif; $\mathrm{h}=$ pengaruh dominan; $\mathrm{i}=$ pengaruh interaksi aditif $\mathrm{x}$ aditif; $\mathrm{j}=$ pengaruh interaksi aditif $\mathrm{x}$ dominan; $\mathrm{l}$ = pengaruh interaksi dominan $\mathrm{x}$ dominan; $\mathrm{tn}=$ tidak berbeda nyata pada taraf $\alpha=5 \%$

Karakter panjang hipokotil memiliki komponen genetik aditif nyata dan dominan tidak nyata (Tabel 6). Nilai aditif lebih besar dibandingkan nilai dominan, artinya bahwa aksi gen aditif lebih berperan pada karakter panjang hipokotil. Pengaruh interaksi gen aditif $\mathrm{x}$ aditif bernilai negatif sedangkan interaksi aditif $\mathrm{x}$ dominan bertanda positif. Menurut Akhtar dan Hazra (2013) interaksi dengan nilai negatif akan menghambat laju kemajuan melalui seleksi sederhana. Hal ini menunjukkan bahwa pengaruh interaksi aditif $\mathrm{x}$ dominan adalah penting sehingga pewarisan panjang hipokotil tomat dipengaruhi oleh epistasis aditif dominan. Hal yang sama dilaporkan Zdravkovic et al. (2011) pada karakter jumlah buah per tandan pada tanaman tomat.

Komponen genetik untuk karakter panjang dan lebar kotiledon adalah nyata pada pengaruh dominan tetapi bertanda negatif, sedangkan untuk interaksi adalah nyata pada pengaruh aditif $\mathrm{x}$ aditif dengan nilai negatif danbernilai positif pada interaksi dominan $x$ dominan (Tabel 6). Pengaruh gen dominan lebih besar dibandingkan dengan pengaruh aditif, artinya gen dominan lebih berperan pada karakter panjang dan lebar kotiledon. Pengaruh interaksi gen antar alel menunjukkan nilai interaksi dominan $\mathrm{x}$ dominan lebih tinggi sehingga lebih berpengaruh pada pewarisan panjang dan lebar kotiledon. Menurut Zdravkovic et al. (2011) interaksi gen aditif $\mathrm{x}$ dominan dan dominan $\mathrm{x}$ dominan lebih baik daripada interaksi aditif $\mathrm{x}$ aditif untuk pewarisan hasil pada tomat. Interaksi gen dominan memungkinkan peluang munculnya gen dominan yaitu hasil tinggi pada generasi berikutnya juga akan semakin besar.

Pengaruh dominan bernilai negatif pada panjang dan lebar kotiledon dan berlawanan dengan pengaruh interaksinya (dominan $\mathrm{x}$ dominan). Menurut Mather dan Jink (1982) jika nilai dominan dan aditif berlawanan dengan masing-masing interaksinya maka tipe interaksi yang paling berperan adalah interaksi duplikat, namun sebaliknya jika tipe interaksinya sama maka yang paling berperan adalah interaksi komplementer. Berdasarkan hal tersebut, panjang dan lebar kotiledon pada penelitian ini dipengaruhi oleh epistasis duplikat.

\section{Heritabilitas Karakter Hipokotil dan Kotiledon Tomat Hasil Persilangan IPB T64 x IPB T3}

Heritabilitas adalah gambaran seberapa jauh penampilan yang teramati (fenotipe) merupakan refleksi dari pengaruh gen (genetik). Nilai heritabilitas dalam arti luas $\left(\mathrm{h}^{2}{ }_{\mathrm{bs}}\right)$ untuk karakter panjang hipokotil, serta panjang dan lebar kotiledon berada pada kisaran tinggi, sedangkan nilai heritabilitas dalam arti sempit $\left(\mathrm{h}^{2}{ }_{\mathrm{ns}}\right)$ berada pada kisaran sedang (Tabel 7). Heritabilitas yang berada pada kisaran sedang berarti pengaruh lingkungan memiliki peran yang besar terhadap penampilan karakter tersebut. Panjang hipokotil serta panjang dan lebar kotiledon pada cabai juga menunjukkan nilai heritabilitas arti luas yang tinggi dan heritabilitas arti sempit pada tingkat sedang (Ritonga, 2013). Beberapa penelitian lain pada tomat juga menunjukkan nilai heritabilitas yang tinggi pada karakter jumlah bunga per tandan (El-Gabry et al., 2014), jumlah rongga per buah (El-Maksoud et al., 2013; Li et al., 2007), jumlah buah per tandan (Hanson et al., 2002). Heritabilitas arti luas yang tinggi berarti karakter yang diamati lebih banyak dikendalikan oleh faktor genetik dibandingkan faktor lingkungan, yang mana ragam genetik terekspresi pada penampilan fenotipik tanaman. 
Tabel 7. Komponen ragam serta heritabilitas arti luas dan arti sempit beberapa karakter tomat

\begin{tabular}{lccc}
\hline \multicolumn{1}{c}{ Komponen } & Panjang Hipokotil & Panjang Kotiledon & Lebar Kotiledon \\
\hline Ragam Aditif $\left(\sigma^{2} \mathrm{D}\right)$ & 0.15 & 0.13 & 0.62 \\
Ragam Dominan $\left(\sigma^{2} \mathrm{H}\right)$ & 1.23 & 1.19 & 2.85 \\
Ragam Lingkungan $\left(\sigma^{2} \mathrm{E}\right)$ & 0.18 & 0.24 & 0.69 \\
Ragam Fenotipe $\left(\sigma^{2} \mathrm{P}\right)$ & 0.50 & 0.24 & 1.51 \\
Ragam Genetik $\left(\sigma^{2} \mathrm{~g}\right)$ & 0.32 & 0.00 & 0.82 \\
Heritabilitas Arti Luas & 0.63 & 0.51 & 0.54 \\
Heritabilitas Arti Sempit & 0.29 & 0.27 & 0.41 \\
\hline
\end{tabular}

Keterangan: $\sigma^{2} \mathrm{E}=$ ragam lingkungan; $\sigma^{2} \mathrm{P}=$ ragam fenotipe; $\sigma^{2} \mathrm{G}=$ ragam genetik; $\sigma^{2} \mathrm{D}=$ ragam aditif; $\sigma^{2} \mathrm{H}=$ ragam dominan; $\mathrm{h}^{2} \mathrm{bs}=$ heritabilitas arti luas; dan $\mathrm{h}^{2} \mathrm{~ns}=$ heritabilitas arti sempit

Jika heritabilitas arti luas nilainya lebih tinggi dibandingkan heritabilitas arti sempit menunjukkan bahwa proporsi ragam dominan lebih besar dibandingkan ragam aditif. Keadaan ini mencerminakan bahwa proporsi ragam dominan lebih besar dibandingkan ragam aditif. Ragam dominan yang tinggi mencerminkan bahwa karakter tersebut baik dalam keadaan heterozigot, sehingga pengembangan hibrida merupakan pendekatan yang tepat untuk perbaikan karakter tersebut dibandingkan melalui proses seleksi (Shalaby, 2013; Garg et al., 2008).

\section{KESIMPULAN}

Karakter warna hipokotil dikendalikan oleh dua pasang gen epistasis dominan-resesif. Gen pengendali warna ungu bersifat dominan terhadap gen pengendali warna hijau pada hipokotil tomat. Karakter panjang hipokotil serta panjang dan lebar kotiledon dikendalikan oleh banyak gen, namun tidak ada pengaruh tetua betina. Aksi gen berdasarkan potensi rasio untuk panjang hipokotil dan panjang kotiledon adalah dominan parsial, sedangkan untuk lebar kotiledon adalah overdominan. Aksi gen berdasarkan uji skala gabungan menunjukkan bahwa panjang hipokotil dikendalikan oleh gen aditif dengan pengaruh epistasis aditif dominan, sedangkan panjang dan lebar kotiledon dikendalikan oleh gen dominan dengan pengaruh epistasis duplikat. Nilai heritabilitas arti luas pada karakter panjang hipokotil serta panjang dan lebar kotiledon tomat yang diamati masuk pada kategori tinggi $(0.63,0.51$ dan 0.54$)$, sedangkan nilai heritabilitas arti sempit berada pada kategori sedang $(0.29,0.27$, dan 0.41$)$.

\section{UCAPAN TERIMA KASIH}

Terima kasih disampaikan kepada Kementerian Riset dan Teknologi yang telah membiayai penelitian ini melalui hibah Insinas tahun 2014 a.n. Sobir dengan kontrak Nomor 25/SEK/ INSINAS/PPK/2014.

\section{DAFTAR PUSTAKA}

Akhtar, S., P. Hazra. 2013. Nature of gene action for fruit quality characters of tomato (Solanum lycopersicum). Afr. J. Biotechnol. 12(20): 2869-2875.

Arif, B.A., S. Sujiprihati, M. Syukur. 2012. Pendugaan parameter genetik pada beberapa persilangan antara cabai besar dengan cabai keriting (Capsicum annuит L.). J. Agron. Indonesia. 40(2): 119-124.

Daya, N., C. Prasad. 1983. Genetic regulation of chromocentres in radish, Raphanus sativus L. Cytologia. 48: 245-252.

Dordevic, R., B. Zecevic, J. Zdravkovic, G. Todorovic. 2010. Inheritance of yield components in tomato. Genetika. 42(3): 575-583.

El-Gabry, M.A.H., T.I.H. Solieman, A.I.A Abido. 2014. Combining ability and heritability of some tomato (Solanum lycipersicum L.) cultivars. Sci. Hortic. 167: 153-157.

El-Maksoud, A.M.M., S.M. Faried, M.M. Sadek. 2013. Gene action and heritability for some characteristics of 
tomato fruit (Lycopersicum esculentum Mill). J. Agric. Chem. Biotech. 4(5): 197-204.

Farzane, A., H. Nemati, H. Arouiee, A.M. Kakhki, N. Vahdati. 2012. The estimate of combining and heterosis for yield and yield components in tomato (Lycopersicon esculentum Mill). J. Bio. Environ. Sci. 6: 129-134.

Garg, N., D.S. Cheema. 2008. Genetics of yield, quality and shelf life characteristics in tomato under normal and late planting conditions. Euphytica. 159: 275-288.

Groenewegen, C., G. King, B.F. George. 1994. Natural cross pollination in California commercial tomato fields. HortScience. 29(9): 1008

Hanson, P.M., J. Chen, G. Kuo. 2002. Gene action and heritability of hightemperature fruit set in tomato line CL5915. HortScience. 37(1): 172-175.

Ibarra-Perez, F.J., N.C. Ellstrand, J.G. Waines. 1996. Multiple paternity in common bean (Phaseolus vulgaris L. Fabaceae). Amer. J. Bot. 86(6): 749-759.

Jones, C.N., P. Mes, J.R. Myers. 2003. Characterization and inheritance of the anthocyanin fruit (Aft) Tomato. J. Hered. 94(6): 449-456.

Kim, H.J., H.R. Lee, J.Y. Hyun, D.C. Won, D.O. Hong, C.H. Harn. 2012. CAPS marker linked to tomato hypocotyl pigmentation. Kor. J. Hort. Sci. Technol. 30(1): 56-63.

Kim, H.J., H.R. Lee, J.Y. Hyun, D.C. Won, D.C. Hong, H. Cho, K.A. Lee, N.H Her, J.H. Lee, C.H. Harn. 2011. Aplication of disease resistance markers for developing elite tomato varieties and lines. Kor. J. Hort. Sci. Technol. 29(4): 336-344.

Knievel, D.C., E.S.M. Abdel-Aal, I. Rabalski, T. Nakamura, P. Huci. 2009. Grain color development and the inheritance of high anthocyanin blue aleurone and purple pericarp in spring wheat (Triticum aestivum L.). J. Cereal Sci. 50: 113-120.

Liang, H., Y. Yu, H. Yang, L. Xu, W. Dong, H. Du, W. Cui, H. Zhang. 2014. Inheritance and QTL mapping of related root traits in soybean at the seedling stage. Theor. Appl. Genet. 127: 2127-2137.

Li, Y., T. Li, D. Wang. 2007. Studies on the inheritance of locule formation in tomatoes (Lycopersicum esculentum Mill). J. Genetics and Genomic. 34(11): 1028-1036

Mather, SK., J.L. Jink. 1982. Biometrical Genetic. Ed ke-3. Chapman and Hall. London.

Phippen, W.B., J.E. Simon. 2000. Anthocyanin inheritance and instability in purple basil (Ocimum basilicum L.). J. Hered. 91(4): 289-96.

Reevesii, A.F. 1973. An observation on natural outcrossing in the tomato (Lycopersicum esculentum L.) in Northwest Arkansas. Arkansas Academy of Science Proc. 27: 24-25.

Ritonga, A.W. 2013. Penyerbukan silang alami beberapa genotipe cabai (Capsicum annum L.) dan penentuan metode pemuliaannya. [Tesis]. Sekolah Pascasarjana. Institut Pertanian Bogor. Bogor.

Rodriguez, G.B., G.R. Pratta, D.R. Liberatti, R. Zorzoli, L.A. Picardi. 2010. Inheritance of shelf life and other quality trait of tomato fruit estimated from F1's, F2's and backcross generations derived from standard cultivar, nor homozygote and wild cherry tomato. Euphytica. 176: 137147.

Roy, D. 2000. Plant Breeding, Analysis and Exploitation of Variation. Narosa Publishing House. New Delhi. 
Shalaby, T.A. 2013. Mode of gene action, heterosis and inbreeding depression for yield and its component in tomato (Solanum lycopersicum L.). Sci. Hortic. 164: 540-543.

Sihaloho, A.N., Trikoesoemaningtyas, D. Sopandie, D. Wirnas. 2015. Identifikasi aksi gen epistasis pada toleransi kedelai terhadap cekaman aluminium. J. Agron. Indonesia. 43(1): 30-35.

Sobir, M. Syukur. 2015. Genetika Tanaman. IPB Press. Bogor

Solieman, T.H.I., M.A.H. El-Gabry, A.I. Abido. 2013. Heterosis, potence ratio and correlation of some important characters in tomato (Solanum lycopersicum L.). Sci. Hortic. 150: 2530.

Syukur, M., S. Sujiprihati, R. Yunianti. 2015. Teknik Pemuliaan Tanaman. Ed. Revisi. Penebar Swadaya. Jakarta.

Syukur, M., H.E. Saputra, R. Hermanto. 2015. Bertanaman Tomat di Musim Hujan. Penebar Swadaya. Jakarta.
[UPOV] International Union For the Protection of New Varieties of Plants. 2011. Tomato. UPOV. Geneva

Villanueva, B., B.W. Kennedy. 1991. Efficiency of indirect selection at selection equilibrium. Theor. Appl. Genet. 81: 166-172.

Villanueva, B., B.W. Kennedy. 1990. Effect of selection on genetic parameters of correlated traits. Theor. Appl. Genet. 80(6): 746-752.

Weber, E. 1959. The genetical analysis of characters with continuous variability on Mendelian basis I. Monohybrid segregation. Genetics. 44(6): 11311139.

Wing, R.A., H.B. Zhang, S.D. Tanksley. 1994 Map-based cloning in crops plants. Tomato as model system: I. Genetic and physical mapping of joinless. Mol. Gen. Genet. 242: 681-688.

Zdravkovic. J., N. Pavlovic, Z. Girek, M.B. Jokanovic, D. Savic, M. Zdravkovic, D. Cvikic. 2011. Generation mean analysis of yield components and yield tomato (Lycopersicon esculentum Mill.). Pak. J. Bot. 43(3): 1575-1580. 